DUNAMIS (Jurnal Teologi dan Pendidikan Kristiani)

Volume 1, Nomor 2 (April 2017)

ISSN 2541-3937 (print), 2541-3945 (online)

http://www.sttintheos.ac.id/e-journal/index.php/dunamis

Submit: 19 April 2017

Accept: 29 April 2017

Published: 29 April 2017

\title{
Mengajarkan Nasionalisme Lewat Momentum Perayaan Paskah: Refleksi Kritis Keluaran 12:1-51
}

\author{
Harls Evan Siahaan \\ Prodi Teologi Kependetaan Sekolah Tinggi Teologi Intheos Surakarta \\ evandavidsiahaan@gmail.com
}

\begin{abstract}
This research is due to social phenomenon in Indoensia lately, where tendention of nationalism is decreasing. Church, which is being a part of this nation component, has responsibility to build its people's sense of nationalism, not mere making them as heavenly citizen. The aim of this article is to point out a biblical study about Passover celebration at the first time in Old Testament, which constituted a commemoration of Israel nationality deliverance from the bondage of Egypt, what was to become an implication of Jesus' death and ressurection event. It uses a historical analysis on biblical text Exodus 12:1-51 with exposition approach for acquiring an event implication in Old Testament theology context. After reading the whole text in the passage, considering its context and genre, then reconstruct its narrative and analyze it, so the conclucion is, that Passover celebration in the first time is God's action to deliver Israel as a nation from Egypt. The research finding is to recommend that Passover celebration in future will be able to increase church's sense of nationality in Indonesia context.
\end{abstract}

Keyword: deliverance; Exodus; nation; nationalism; Passover

\begin{abstract}
Abstrak
Artikel ini adalah sebuah penelitian yang berkaitan dengan fenomenologi sosial di Indonesia dewasa ini, di mana kecenderungan memupusnya sikap nasionalisme anak bangsa. Gereja Tuhan sebagai bagian dari komponen bangsa ini memiliki tanggung jawab untuk membangun rasa nasionalisme umat, tidak hanya sekadar menjadikannya warga surga seperti idealisme teologi. Tujuan artikel ini untuk menunjukkan kajian biblikal tentang perayaan Paskah yang secara asali merupakan peringatan tentang perjuangan pembebasan Israel sebagai sebuah bangsa, yang di kemudian hari memberikan implikasi teologis pada peristiwa kematian dan kebangkitan Kristus. Metode yang digunakan adalah analisis historis pada teks Keluaran 12:151 dengan pendekatan eksposisi, untuk mendapatkan implikasi peristiwa dalam konteks teologi Perjanjian Lama. Setelah membaca teks secara keseluruhan, lalu memperhatikan konteks dan genre sastera, merekonstruksi narasi teks dan menganalisisnya, maka disimpulkan bahwa pada awalnya peristiwa Paskah merupakan perbuatan ilahi untuk membebaskan Israel dari penjajahan Mesir. Temuan pembahasan dan simpulan merekomendasikan agar momentum perayaan Paskah dapat meningkatkan rasa nasionalisme gereja dalam konteks Indonesia.
\end{abstract}

Kata kunci: bangsa; Keluaran; nasionalisme; Paskah; pembebasan 


\section{PENDAHULUAN}

Perayaan Paskah merupakan salah satu hari suci orang Kristen di samping Hari Natal. Pada umumnya perayaan Paskah ini dilakukan bertepatan dengan momentum kematian dan kebangkitan Yesus. Baik kematian dan kebangkitan Yesus Kristus merupakan dua hal yang tidak dapat dipisahkan; karena kematian tanpa kebangkitan tidak ada artinya (band. 1 Kor. 15:17), dan sebaliknya kebangkitan tidak pernah ada tanpa kematian. Perayaan ini secara tradisi selalu jatuh di antara bulan Maret atau April, tidak pernah jatuh pada penanggalan yang sama tiap tahunnya seperti halnya Natal. Hal ini dikarenakan perayaan Paskah dalam tradisi Yahudi menggunakan kalender dengan sistim penanggalan bulan (Kel. 12:2), yang berbeda dengan Natal dengan penanggalan matahari. ${ }^{1}$

Paskah yang diperingati oleh orang Kristen di seluruh dunia merupakan adopsi dari hari raya suci kaum Yahudi dengan momentum perayaan tentang pembebasan bangsa Israel dari penjajahan dan perbudakan Mesir. Pada masa Perjanjian Baru, Yesus pun merayakan Paskah atau yang dikenal juga dengan istilah Hari Raya Roti Tidak Beragi bersama para murid

\footnotetext{
${ }^{1}$ Steven L. Ware "Cracking The Code of Easter or, Understanding hy The Date of Easter 'Hops' All Over The Calendars of March and April" Jurnal Jaffray, Vol. 13, No. 2, Oktober 2015: 169-180
}

kematianNya (Mat. 26:17; Mark. 14:12; Luk. 22:1, 7). Selama tujuh hari orang Israel harus makan roti tidak beragi; di mana pada hari pertama mereka tidak diperbolehkan untuk bekerja berat melainkan harus mempersembahkan korban bagi Tuhan. William Dyrness menjelaskan bahwa perayaan itu seperti sebuah ibadah keluarga yang dilakukan sebagi upacara peringatan. ${ }^{2}$ Selama masa perayaan itu orang Israel kembali mengingat masa perbudakan dan bagaimana Tuhan membawa mereka keluar dari negeri itu.

Pokok peringatannya adalah perbuatan Allah di masa lalu atas umatNya, Israel, dengan kata kunci pembebasan atau kemerdekaan. Setelah sekian lama Israel ada dalam perbudakan Mesir, dan selama itu juga mereka terus berseru dan berdoa memohon pertolongan Tuhan, akhirnya Allah menunjuk Musa menjadi pemimpin untuk membebaskan umat-Nya itu, serta membawa mereka ke tanah yang telah disediakan lewat perjanjian Abraham.

Pengajaran tentang Paskah dalam konteks iman Kristen merupakan hal yang paling mendasar, karena ini terkait dengan pokok Kristologi atau Soteriologi yang merupakan sentralitas iman Kristen. Teologi Kristen berpusat pada Kristus dengan semua karyaNya, terutama karya

\footnotetext{
${ }^{2}$ William Dyrness, Tema-tema dalam Teologi Perjanjian Lama (Malang: Gandum Mas, 2004), 128
} 
penebusan lewat kematian di kayu salib dan diikuti kebangkitanNya. Pengajaran tentang Paskah dimulai dari Sekolah Minggu, dengan cara dan pendekatan yang berbeda dengan kelompok dewasa atau pemuda. Cerita tentang kematian dan kebangkitan Yesus menjadi satu hal yang wajib dalam pengajaran atau doktrin Kristen. Demikian juga dengan konten pelajaran Pendidikan Agama Kristen di sekolah, sekalipun mungkin tidak dalam bentuk materi ajar yang khusus, namun esensi penebusan atau karya keselamatan Kristus menjadi kerangka teologis setiap materi ajar.

Intinya, cerita Paskah, baik dalam bentuk khotbah umum di gereja, cerita pelajaran di Sekolah Minggu atau remaja dan pemuda, bahkan hingga materi ajar di sekolah adalah tentang karya keselamatan lewat penebusan Kristus, baik kematian dan kebangkitan. Peristiwa yang pada awalnya merupakan perayaan untuk memperingati pembebasan umat Israel dari penjajahan serta perbudakan dalam konteks kebangsaan $^{3}$, berimplikasi rohani dalam konteks teologi Kristen. Hal ini dikarenakan semua peristiwa Alkitab, dari awal Perjanjian Lama hingga akhir Perjanjian Baru dipandang dalam terang sejarah keselamatan (helisgeschichte) sebagai benang merahnya. Akibatnya,

\footnotetext{
${ }^{3}$ George W. Knight, Adat Istiadat Alkitab dan Keunikannya dalam Gambar (Jakarta: BPK Gunung Mulia, 2015), 40-41
}

beberapa peristiwa historis, seperti halnya Paskah, hanya menghasilkan makna teologis saja.

Hal tersebut tidak sepenuhnya salah, bahkan sah saja, karena memang demikian tujuan penulis Alkitab, yakni menghadirkan implikasi rohani bagi para pembacanya. Teologisasi pembebasan Israel dari penjajahan dan perbudakan Mesir menjadi pembebasan manusia atas dosa. Mesir adalah simbol keterikatan dosa masa lalu, sehingga karya Allah atas umatNya, Israel, harus dimaknai secara rohani atau teologis. Sekali lagi, ini bukanlah sebuah teologisasi yang salah, karena memang demikian Perjanjian Baru memaknainya. Namun, teologi Kristen juga seharusnya memberikan tempat atau porsi yang seimbang. Artinya, tidak semua teologisasi atas peristiwa historis meninggalkan fakta historis dan mempertahankan makna teologis saja.

Bagi Israel peristiwa Paskah tidak mengabaikan momentum kebangsaan, karena pembebasan Allah dengan cara yang ajaib atas mereka merupakan tindakan atas nama sebuah umat dan sekaligus bangsa. Israel tentu tidak mengabaikan peristiwa teologis di sana, pada karya pembebasan ilahi tersebut. HarperCollins Bible Dictionary menunjukkan sebuah peran yang unik perayaan Paskah dalam kehidupan Israel, yakni tentang penebusan Allah yang 
luar biasa, yang mewakili perasaan cinta Allah, yang diwujudkan dalam tindakan penyelamatan-Nya kepada mereka, sehingga kekuatan pesannya masih terus relevan hingga tiga ribu tahun masa di depannya. ${ }^{4}$ Hari raya Paskah inilah yang diwariskan secara turun-termurun dalam bentuk perayaan keluarga untuk memperlihatkan harapan kepada Israel tentang kelepasan atas persoalan diskriminasi sosial dan keagamaan.

Signifikansi peristiwa itu adalah pada perannya yang unik dalam kehidupan Israel; di satu sisi adalah pembebasan dalam konteks penjajahan fisik oleh Mesir, di sisi lain merupakan karya penebusan Allah (YHWH). Pada titik ini Israel menyadari akan penyertaan dan campur tangan Tuhan yang ajaib atas kemerdekaan sebuah bangsa.

Kekristenan telah menarik implikasi teologis dari peristiwa historis Paskah hingga ke salib Kristus, sementara Israel condong pada pijakan ideologis kebangsaannya. Berawal dari penyelamatan atas kaum Israel di tanah Gosyen; Tuhan melewati (Ibrani: passover) kediaman Israel yang pada ambang pintunya dilaburi darah anak domba. Peristiwa ini sangat kuat pesan

\footnotetext{
${ }^{4}$ Paul J. Achtemeier (gen. ed.), The HarperCollins Bible Dictionary (New York: HarperCollins, 1996), 811
}

soteriologisnya, sehingga tidak heran jika arah khotbah dan materi ajar tentang peristiwa tersebut selalu berakhir dengan simpulan dan implikasi teologis tentang penebusan dosa.

Israel sebagai sebuah bangsa adalah konsep yang tidak dapat diabaikan begitu saja dalam Alkitab. Israel jangan hanya dilihat sebagai sebuah umat yang senantiasa menghadirkan peristiwa iman belaka, melainkan harus berimbang dengan identitas kebangsaannya, sehingga peristiwa yang terjadi pun merupakan fakta historis yang memiliki implikasi bukan hanya pada persoalan teologis. Dalam konteks kebangsaan, maka peristiwa Paskah bagi Israel harus diletakkan sama dengan peristiwa kemerdekaan bangsa lain, seperti halnya Indonesia. Peristiwa paskah pada akhirnya juga harus dilihat pada nuansa nasionalis.

Ada kecenderungan yang kuat gereja berorientasi pada persoalan iman yang vertikal dan hanya sedikit memperhatikan persoalan horisontal. Gereja cenderung disibukkan dengan persoalan surgawi, seakan anti terhadap tanggung jawab sosial terlebih politik. Gereja merasa persoalan sosial dan politik bukanlah hal rohani. Hasilnya tidak sedikit gereja atau pendeta yang anti sosial terlebih politik. Tanggung jawab gereja bukanlah hanya pada persoalan kerohanian umat, melainkan juga 
lingkungan di mana gereja berada, dari level yang kecil hingga luas. Tanggung jawab politik tidak harus melibatkan gereja dalam politik praktis, melainkan menghilangkan sikap apatis.

Dalam konteks tanggung jawab sosial itulah gereja harus dapat memberikan pengajaran kepada jemaatnya. Khotbahkhotbah mingguan tidak lagi didominasi oleh tema-tema kesalehan pribadi tanpa memahami tanggung jawab sosialnya. ${ }^{5}$ Menjadi garam dan terang harus dimaknai secara holistik, sehingga orang percaya menyadari manfaat dan fungsinya di tengah dunia. Gereja tidak dapat menjadi saksi jika hanya ada di dalam dunia yang mengasingkan diri dari hiruk pikuk dunia sekuler. Gereja tidak dapat terus-menerus menarik diri demi mempertahankan kesalehan, berharap Yesus segera datang kembali agar semua persoalan dunia terselesaikan. Gereja harus menjadi bagian dari kehidupan bersama, bukan justru alergi dan eksklusif.

Ada semacam kurangnya partisipasi orang Kristen di tengah persoalan yang sedang melanda kehidupan bangsa ini. Gereja kurang memberi identitas dirinya pada ruang publik, karena kekuatiran akan penolakan dan kecurigaan misi kristenisasi. Terlebih pada satu hingga dua dasa warsa

\footnotetext{
${ }^{5}$ Junihot M. Simanjuntak, "Kristologi Sebagai Pusat dalam Pembinaan Warga Gereja", Jurnal Teologi Stulos, Vol. 13, No. 1 (April 2014): 137
}

terakhir, ketika eskalasi persoalan intoleransi semakin meningkat, bahkan memicu hadirnya radikalisme, membuat ruang gerak kekristenan semakin sempit dan eksklusif. Sepertinya nas-nas tentang akhir zaman telah meningkatkan keyakinan bahwa dunia ini akan semakin bobrok dan hancur tanpa dapat dibenahi kecuali oleh kedatangan Kristus yang kedua kali. Semua usaha manusia akan sia-sia, karena dunia sedang menuju “takdir"nya, yakni kehancuran.

Di tengah semakin meningkatnya sikap anti-nasionalisme yang melanda anak bangsa, ditambah semakin gencarnya penjajahan ideologi yang ingin menggusur Pancasila dan UUD 1945 sebagai fondasi kehidupan berbangsa dan bernegara ${ }^{6}$, gereja harus semakin mengobarkan spirit nasionalisme. Gereja harus menguatkan sendi nasionalisme umat, agar dimensi penyelamatan ilahi tidak hanya berbicara pada tatanan rohani melainkan semua aspek kehidupan. Pokok pikiran tentang kehidupan di dunia yang bersifat sementara tidak lantas melegitimasi ide kesalehan yang mengabaikan partisipasi dalam masyarakat.

Indonesia sedang mengalami krisis nasionalisme, terutama kelompok generasi

\footnotetext{
${ }^{6}$ Midran Zusron Alfaqi, "Melihat Sejarah Nasionalisme Indonesia Untuk Memupuk Sikap Kebangsaan Generasi Muda", Jurnal Civics, Vol. 13, No. 2 (Desember 2016): 215
} 
muda. ${ }^{7}$ Maraknya aksi intoleransi dan radikalisme merefleksikan sebuah ancaman terhadap identitas kebangsaan yang tergerus oleh arogansi yang mengatasnamakan agama. Ditambah lagi dengan dampak globalisasi oleh kemajuan teknologi dan informasi yang telah menghadirkan pola westernisasi yang menggeser budaya ketimuran Indonesia. ${ }^{8}$ Inilah pranata sosial di mana gereja ada di tengah-tengahnya, sehingga sangat naif jika bersikap apatis hingga mengabaikan degradasi moral di luar sementara khotbah mimbar di dalam lantang berbicara tentang transformasi spiritual.

Gereja harus dapat menanamkan sikap nasionalisme, yakni rasa memiliki bangsa ini, sebagai refleksi iman yang tidak kalah pentingnya dengan persoalan surga. Idrus Ruslan menyebutkan bahwa modal sosialkultur dan spiritual menjadi penting selain modal material dalam membangun suatu bangsa. ${ }^{9}$ Fungsi gereja sebagai modal spiritual, bahkan sosial-kultural dalam membangun nasionalisme sangat dibutuhkan. Kebutuhan ini tidak hanya

\footnotetext{
${ }^{7}$ Amrah. "Mengulik Pengembangan Nasionalisme Generasi Muda." Jurnal Publikasi Pendidikan, Vol. 6, No. 2, Juni 2016: 94.

${ }^{8}$ Hendropriyono, "Ide dan Praksis NeoNasionalisme dalam Menghadapi Tantangan Globalisasi”, Jurnal Filsafat UGM, Vol. 18, No. 1 (April 2008): 76-80

${ }^{9}$ Idrus Ruslan. "Membangun Nasionalisme Sebagai Solusi Untuk Mengatasi Konflik Sara di Indonesia”, Jurnal TAPIS, Vol. 10, No. 1, JanuariJuni 2010: 7
}

bersifat idealistis melainkan butuh implementasi praksis untuk mengenalkan citra gereja di tengah masyarakat luas yang heterogen. Gereja tidak melakukan kristenisasi, melainkan dengan identitas khasnya memberikan pengaruh atau dampak secara kultur, menciptakan habit yang mengamalkan nilai-nilai kebangsaan.

Mengapa acap kali kekristenan dianggap tamu atau pendatang di bumi Indonesia, dan lebih sering dikenal dengan identitas baratnya? Hal itu disebabkan gereja yang kurang membumi dan membudaya di tanah air Indonesia. ${ }^{10}$ Sepertinya menyanyikan lagu-lagu pujian atau rohani dipandang lebih menyukakan Tuhan dibanding melantumkan epik nasionalisme. Gereja merasa tidak rohani untuk menghadirkan identitas nasional dalam agenda perayaan Kristiani. Bagaimana tidak, tidak sedikit gereja, lewat komisi pemuda dan remaja lebih memilih merayakan ibadah Valentine's Day dibanding mengadakan ibadah Sumpah Pemuda atau Kesaktian Pancasila. Gereja harus memiliki ruang bagi kehidupan berbangsa, dan mengisi ruang kebangsaan.

Perayaan Paskah yang mengambil setting Keluaran 12 secara keseluruhan tidak berhenti pada implikasi rohani tentang

\footnotetext{
${ }^{10}$ Desti Samarena, "Berteologi dalam Konteks Indonesia Modern", Evangelikal: Jurnal Teologi Injili dan Pembinaan Warga Jemaat, Vol. 1, No. 1, Januari 2017: 23
} 
penebusan Yesus di kayu salib. Jika kacamata yang digunakan adalah Perjanjian Baru, maka hal itulah yang terjadi. Namun, peristiwa Perjanjian Lama juga perlu dipandang secara mandiri, sebagai teologi biblikal yang mengeluarkan idenya sendiri dengan konteks pemahamannya yang tidak harus diasumsikan oleh tema-tema Perjanjian Baru. Dalam konteks peristiwa awal, perayaan Paskah yang dikenang melalui perayaan tahunan, merupakan napak tilas bangsa Israel menuju kemerdekaannya. Pembebasan dari tanah Mesir merupakan momentum nasional yang terus akan dikenang oleh orang Israel dari generasi ke generasi melalui perayaan Paskah.

Kajian ini akan menjawab sebuah pada pertanyaan peneltiian, bagaimana seharusnya gereja atau kekristenan memahami peristiwa Paskah dalam bingkai teologi Perjanjian Lama, dan mengaktualisasikannya lewat kehidupan kekristenan saat ini dalam konteks hidup berbangsa.

\section{METODE}

Penelitian ini bersifat analisis teks tentang peristiwa Paskah yang muncul dalam Alkitab, yakni Keluaran 12:1-51. Pendekatan penelitian adalah kualitatif dengan metode eksposisi pada teks Keluaran 12:1-51. Metode eksposisi digunakan untuk memahami secara mendalam makna dari cerita historis kisah yang disampaikan oleh penulis kitab ini kepada para pembacanya.

\section{Survei Kitab Keluaran}

Kitab Keluaran merupakan salah satu dari lima kitab yang ditulis oleh Musa. Memang ada perdebatan tentang kepenulisan dengan berbagai argumentasi seperti teori sumber. ${ }^{11}$ Penelitian ini tidak akan membahas hal tersebut, karena munculnya teori sumber lebih banyak dipengaruhi oleh filsafat rasionalisme dan pencerahan, sehingga teologi tidak harus menggunakan teori itu sebagai pijakan. Kepenulisan Musa atas kitab ini secara tidak langsung diakui melalui kutipan dalam Perjanjian Baru.

Dari bentuk sasteranya, kitab Keluaran termasuk dalam bentuk prosa, lebih khusus lagi narasi, karena penulis sedang menceritakan sebuah peristiwa faktual di tanah Mesir pada masa itu. Penulis sebagai tokoh di kisah itu mengetahui betul peristiwa yang terjadi, sehingga apa yang disampaikan bukanlah sekadar narasi yang cenderung berbau fiksi. Ini adalah narasi biblikal yang harus dipahami dalam kerangka berpikir yang teologis. Pesan yang ingin disampaikan dalam narasi

\footnotetext{
${ }^{11}$ Andrew E. Hillton dan John H. Walton, Survei Perjanjian Lama (Malang: Gandum Mas, 1996), 168-169
} 
biblikal menjadi poin penting tanpa mengabaikan fakta dari peristiwa yang terjadi.

Narasi biblikal tidak hanya sekadar cerita untuk menyampaikan pesan, namun juga mempertimbangkan peristiwa yang terjadi. Dalam hal inilah keterlibatan Allah dalam sejarah manusia menjadi satu bagian yang penting untuk dimengerti. Keterlibatan Allah tidak serta-merta membawa manusia keluar dari lintasan naturnya, seperti apa yang dipahami sebagai peristiwa iman (faith event). Hanya teologi dalam balutan rasionalisme yang kental pascareformasi sajalah yang akan mengabaikan kehadiran ilahi dalam sejarah manusia, sehingga narasi biblikal hanya dipandang sebagai mitologi.

Peristiwa dalam Keluaran 12:1-51 merupakan bagian dari narasi yang lebih luas lagi dalam Alkitab, khususnya Perjanjian Lama. Gordon D. Fee dan Douglas Stuart membagi tiga level tentang narasi biblikal ini,

The top level is that of the whole universal plan of God worked out through His creation...key aspects of the middle level center on Israel...Then there is the button level. Here are found all the hundreds of individual narratives that make up the other two levels. ${ }^{12}$

Bagian yang paling mendasar (button level) dari narasi itulah yang membentuk narasi

\footnotetext{
${ }^{12}$ Gordon D. Fee and Douglas Stuart, How to Read The Bible for All its Worth (Michigan: Grand Rapids, 1982), 74
}

yang lebih luas dan besar lagi. Jadi kisah Paskah ini sejatinya harus dipahami dari dua level narasi di atasnya, Israel dan universal.

Peristiwa yang dikisahkan dalam Keluaran 12:1-51 merupakan cerita atau sejarah dengan makna yang terkandung di dalamnya sebagai sebuah pesan. Sehingga ketika membaca peristiwa Paskah yang ada dalam nats tersebut haruslah dimengerti dalam konteks yang lebih luas: Israel dan universal.

\section{Konteks}

Konteks di sini bukan sekadar letak nats dan kaitannya dengan nats lain dalam Alkitab., melainkan juga tentang situasi sosial-politik saat itu. Konteks umum Keluaran 12:1-51 tentunya keseluruhan kitab Keluaran yang merupakan bagian dari karya teologis Musa. Konteks khusus merupakan nats paralel yang berbicara tentang paskah di tempat lain, baik dalam Perjanjian Lama hingga Perjanjian Baru. Nats-nats yang disebut pada bagian sebelumnya menunjukkan keterkaitan tentang konsep Paskah hingga dunia Perjanjian Baru.

Konteks sosial-politik yang terjadi pada Keluaran 12:1-51 merupakan sebuah keadaan Israel yang terjajah dan menjadi budak di negeri orang. Bisa jadi narasi ini tidak hanya memberikan pesan secara 
teologis, melainkan pesan kebangsaan bagi pembaca pertamanya. Gereja bukan merupakan pembaca pertama kitab Keluaran sehingga pesan yang ditangkap jauh lebih berkarakter Perjanjian Baru, di mana Paskah berimplikasi pada korban Yesus dalam bingkai soteriologi. Pembaca pertama kitab ini adalah orang Israel yang tidak memiliki pandangan yang jelas tentang soteriologi Perjanjian Baru, sehingga pesan dengan nuansa sebuah bangsa jauh lebih dipahami oleh pembaca.

Keadaan perbudakaan yang dialami Israel menghasilkan sebuah fanatisme kebangsaan yang kuat. Sekalipun ada campur tangan ilahi dalam setiap peristiwa dan sejarah Israel, namun setting peristiwa itu selalu dikaitkan dalam konteks sosial dan politik. Kehidupan Israel senantiasa dikaitkan dengan kerajaan atau bangsa yang ada di sekitarnya. Demikian juga ketika Perjanjian Lama mengisahkan tokoh-tokoh seperti Yosua, para Hakim, hingga Daud, senantiasa persoalan yang dihadapi adalah tentang hubungan antar bangsa atau kerajaan, sehingga situasi tersebut lebih mengobarkan semangat kebangsaan. Analisis yang akan dilakukan bukan pada teks, melainkan pada peristiwa atau analisis historis; bagaimana memahami peristiwa Paskah tidak hanya dalam kerangka teologis melainkan historisnya.

\section{Genre Sastera}

Mengidentifikasi atau menentukan genre sastera sebuah kitab, terutama dalam studi Perjanjian Lama merupakan hal yang penting. Menafsirkan teks dari sastera puisi dan prosa adalah dua hal yang berbeda dalam kerangka teologi Perjanjian Lama. Demikian juga dengan nubuatan dan hukum. Biasanya penggunaan bahasa atau majas menjadi pola-pola yang sering digunakan para penulis Perjanjian Lama, khususnya para nabi dan syair-syair, untuk menyampaikan serentetan pesan.

Hal yang tidak mungkin mengartikan bahasa dengan pola puisi dan syair Ibrani melalui pendekatan prosa. Memang bahasa puisi (majas) tidak hanya digunakan dalam sastera jenis puisi, karena tidak jarang dalam beberapa dialog naratif menggunakan pola-pola sedemikian, bahasa-bahasa figuratif atau puitis. Para nabi dalam penyampaian pesan tidak selalu menggunakan teguran frontal, mereka menggunakan bahasa atau pola puisi. Kerangka berpikir seperti ini harus diperjelas, terutama dalam analisis teks Perjanjian Lama.

Kitab Keluaran termasuk dalam kelompok kitab yang ditulis oleh Musa, atau sering disebut Taurat; dalam konteks Ibrani istilah ini berarti ketentuan atau Hukum. Kitab Taurat ibarat undang-undang bagi hidup orang Israel, karena esensinya 
adalah pengajaran dan instruksi. ${ }^{13}$ Dalam penyampaian pesan kepada para pembaca kitab Pentateukh Musa menggunakan pola yang beragam. Pada bagian Keluaran 12:151 ini Musa menggunakan narasi historis tentang keluarnya bangsa Israel. Nama kitab Keluaran ini merupakan tema makro dari semua yang ada dalam kitab, yaitu tentang keluarnya bangsa Israel dari perbudakan Mesir menuju negeri yang dijanjikan bagi mereka, yakni Kanaan.

Kitab Kejadian, yang pertama dari Pentateukh, merupakan narasi tentang terjadi dan adanya segala sesuatu, di mana Musa menceritakan bagaimana segala sesuatu yang ada di sekitar manusia terjadi oleh karena satu penyebab, yakni Allah sebagai Pencipta. Musa menggunakan prosa narasi untuk menggambarkan kekuasaan dan kehebatan Allah Sang Pencipta. Dalam Keluaran, narasi Musa mendeskripsikan proses keluarnya bangsa yang telah dipilih itu menuju tempat yang juga sudah dipilih atau ditentukan oleh Allah. Di sini penggunaan prosa narasi sebagai sastera untuk menyampaikan baik pesan maupun laporan peristiwa historis menjadi begitu penting. Artinya, secara umum Musa menggunakan prosa narasi, walaupun dalam beberapa kasus ia juga menggunakan bahasa atau pola puisi.

\footnotetext{
${ }^{13}$ Gary Edward Schnittjer, The Torah Story (Malang: Gandum Mas, 2015), 34
}

\section{ANALISIS DAN \\ HASIL PEMBAHASAN}

Analisis teks Keluaran 12:1-51 mengabaikan beberapa pokok atau langkah eksegetis, seperti penggunaan beberapa terjemahan pembanding atau kritik aparatus. Pengabaian itu tidak berdampak signifikan dalam format penelitian ini, karena baik terjemahan pembanding maupun kritik hanya bersifat non-teknis dalam upaya memahami analisis teks atas narasi historis peristiwa Paskah yang ada di dalamnya. Penelitian lebih memfokuskan pada rekonstruksi narasi historis dan teologis kisah Paskah pada awalnya untuk menarik ide relevan dan aktualisasinya bagi peran gereja di masa kini dalam konteks hidup berbangsa di Indonesia.

\section{Etimologi Paskah}

Kata Paskah yang digunakan dalam teks Lembaga Alkitab Indonesia berasal dari kata Ibrani: pesah (חָֻּ), yang secara leksikal berarti melewati (to pass over). ${ }^{14}$ Sebenarnya ada kata lain seperti עָבר (abar) yang juga berarti melewati. Hanya kata ini lebih kepada melewati sebuah tempat atau jalan (through), sementara pesah memiliki pengertian seperti melewatkan sebuah kesempatan atau tidak memperhitungkannya; menyerupai istilah "skip" pada sebuah proses instalasi.

\footnotetext{
${ }^{14}$ Achtemeier, Loc.Cit.
} 
Kisah Keluaran 12:1-51 menjelaskan dengan bernas tentang pemahaman paskah atau pesah, di mana tulah kematian anak sulung tidak terjadi atau dialami oleh anakanak Israel. Mereka terlewatkan dari hukuman yang sedang melanda seluruh Mesir. Hukuman ini merupakan rangkaian dari sepuluh tulah yang dilakukan Allah terhadap Mesir, dalam rangka membuat Firaun membebaskan orang Israel keluar dan menuju destinasinya, yakni Kanaan. Setelah empat ratus tahun lebih dalam perbudakan Mesir, dan sepanjang itu pula orang Israel berseru kepada Allah untuk sebuah pembebasan, maka Tuhan Allah mulai melakukan misi pembebasan dari memilih Musa sebagai pemimpin hingga melakukan konfrontasi terhadap Firaun menuntut pembebasan Israel dan pada akhirnya mereka keluar dari Mesir.

\section{Rekonstruksi Historis-Teologis}

Konteks Keluaran 12 secara setting historisnya dimulai dari Keluaran 6, di mana Musa diutus Allah menemui Firaun untuk memintanya membebaskan orang Israel (Kel. 6:10). Sempat terjadi dialog penolakan oleh Musa dengan mengajukan beberapa alasan, namun akhirnya ia menyetujuinya. Keluaran 6-10 memuat sebuah proses diplomasi yang cukup alot antara Musa dengan Firaun. Tulah pertama hingga sembilan menjadi indikasi betapa kerasnya Firaun mencengkeram Israel; ia tetap menginginkan perbudakan itu ada. Sebentar Firaun melemah karena tulah yang ditimpahkan atas dia dan bangsa Mesir, namun tidak lama kemudian ia kembali mengeraskan hatinya untuk menghalangi Musa. Hingga akhirnya tulah kesepuluh memaksanya untuk melepaskan Israel.

Pasal 11-12 merupakan puncak dari diplomasi Musa dengan Firaun. Tindakan pamungkas Allah untuk menulahi Firaun menjadi momentum Paskah selanjutnya. Pada titik ini Allah sedang melakukan persiapan untuk membebaskan bangsa Israel. Persiapan itu seperti prosesi ritual keagamaan, di mana setiap rumah orang Israel diharuskan menyembelih domba dan membubuhkan darahnya pada kedua tiang pintu dan ambang atas rumah mereka (Kel. 12:1-7). Tuhan memberikan opsi: boleh kambing atau domba, boleh juga dua rumah tangga berkolaborasi. Intinya, harus ada yang disembelih dan darahnya itulah yang menjadi tanda agar hukuman Allah tidak tertimpa atas rumah mereka.

Apa yang dilakukan oleh orang Israel sejatinya jangan dibatasi pada kegiatan ritual kegamaan, di mana ukurannya adalah perintah atau ketentuan dari Tuhan, yang dalam hal ini Musa menjadi perantaranya. Pembebasan Israel adalah menjadi produk tumpang tindih dalam pemahamannya di kemudian hari, khususnya bagi gereja. Pembebasan itu tidak hanya dibatasi pada 
persoalan dosa seperti yang selalu dipahami dalam konteks penebusan Kristus; itu murni pembebasan sebuah bangsa dari penjajahan dan perbudakan, sebuah persoalan nasionalisme. Sekali lagi, konteksnya adalah Israel sebagai sebuah bangsa, tidak hanya sebatas umat Allah.

Konsep Israel sebagai sebuah bangsa tidak serta-merta akan menghilangkan identitas umat Allah, terlebih dengan panggilanya sebagai bangsa yang kudus dan kerajaan Imam (Kel. 19:6). Dikotomi bangsa dan umat tidak harus dimengerti sebagai dua hal yang saling berlawanan. Jika beranjak pada panggilan Israel dalam Keluaran 19:6, maka dapat diindikasikan bahwa tujuan Allah adalah untuk membentuknya sebagai sebuah bangsa. Istilah bangsa dalam nas ini adalah: (goy), dibedakan dengan istilah yang sering digunakan sebelumnya (Kel. 5:1; 7:14; 8:1; 9:1; 10:3), yakni: עِ (am) yang sering diartikan umat dalam Perjanjian Lama. ${ }^{15}$ Kata juga untuk menunjuk bangsa lain selain Israel dalam Perjanjian Lama. Prinsip ini menunjukkan Israel yang sama kedudukannya dengan bangsa lain, seperti Mesir, Babilonia, atau Asyur.

\footnotetext{
${ }^{15}$ Walter C. Kaiser, Teologi Perjanjian Lama (Malang: Gandum Mas, 2013), 141
}

Perayaan Paskah di gereja saat ini mengambil setting penggenapan nubuat ataupun simbol tentang anak domba yang disembelih untuk sebuah karya penebusan atas dosa. Simbol atau nubuatan itu tidak salah atau terkesan memaksa, karena memang Perjanjian Baru mengindikasikan hal itu, bahwa Yesus adalah Domba Paskah (1 Kor. 5:7) yang disembelih untuk pembebasan atas dosa. Penebusan, pembebasan, kemerdekaan menjadi kata kunci tematik dalam peristiwa Paskah, baik yang pertama maupun dalam peristiwa salib. Sehingga, pada praktiknya perayaan Paskah gerejawi selalu membawa nuansa salib dan korban tebusan dosa.

Peristiwa Paskah yang senantiasa dirayakan Israel setelah keluar dari Mesir merupakan momentum untuk mengenang pembebasannya. Ini sama halnya seperti sebuah negara yang sedang memperingati hari kemerdekaannya, katakanlah itu Indonesia. Perayaan kemerdekaan yang diperingati setiap tanggal 17 Agustus merupakan momentum untuk mengenang pembebasan bangsa ini dari belenggu penjajahan. Kemerdekaan itu juga dipercaya sebagai campur tangan Tuhan di dalamnya, seperti yang disebut dalam pembukaan UUD 1945: "Oleh karena rahmat Allah..." Ini pengakuan dari sebuah kesadaran bahwa kemerdekaan itu tidak mungkin terjadi tanpa campur tangan 
Tuhan di dalamnya. Seperti itu juga rasa yang ada di dalam diri orang Israel, mana kala merayakan Paskah.

Peristiwa salib merupakan satu hal dan sangat penting dalam kehidupan manusia, terlebih yang percaya kepada Yesus. Sedemikian pentingnya peristiwa itu bagi iman Kristen bukan berarti mengabaikan fakta historis tentang peristiwa itu. Ini tidak seperti memilah historical Jesus dan Christ of faith. Ini menekankan tentang pentingnya dimensi sejarah dalam sebuah peristiwa, karena dengan demikian peristiwa tersebut benar-benar terjadi, tidak hanya untuk mencari implikasi teologis. Keterkaitan peristiwa salib dengan Paskah di mesir sepertinya harus dibatasi pada memahami simbol dalam Perjanjian Lama. Artinya, apa yang Musa sampaikan dalam bentuk narasi tidak untuk memberikan makna teologis pada konstruksi Perjanjian Baru. Musa menyampaikan sesuatu yang dipahami dalam konteks Israel.

Musa terikat dengan apa yang menjadi nilai-nilai nasionalismenya, sehingga apa yang dilakukannya harus juga dipahami dalam kerangka nasionalisme. Rasa cinta terhadap bangsanya pernah diekspresikan dalam sebuah doa kepada Tuhan Allah dalam Keluaran 32:32, "Tetapi sekarang, kiranya Engkau mengampuni dosa mereka itu dan jika tidak, hapuskanlah kiranya namaku dari dalam kitab yang telah
Kautulis." Hanya kecintaan akan bangsa yang mampu membuat seseorang rela kehilangan jaminan yang paling berharga demi bangsanya, dan itulah Musa.

Perayaan Paskah gerejawi cenderung mengambil setting peristiwa keluarnya Israel dari Mesir sebagai peristiwa teologis, sehingga semua anasir di dalamnya diartikulasikan dalam sebuah peristiwa iman. Ini bukan kesalahan, karena memang simbol Perjanjian Lama ini bermuara pada peristiwa salib, ditambah lagi Yesus disebut sebagai Anak Domba Allah atau Domba Paskah yang disembelih. Namun, gereja juga tidak seharusnya menghilangkan permenungan kebangsaan seperti yang dilakukan Israel sebelum peristiwa salib. Gereja tidak akan melakukan kontemplasi tentang pembebasan Israel sebagai bangsa atau negara seperti sekarang ini, namun lebih kepada perenungan esensi kebangsaan, bahwa pembebasan itu bersifat holistik.

Perayaan Paskah yang ada di dalam gereja sekarang ini harus menarik dimensi nasionalisme ke dalam penghayatan iman umat, sehingga perayaan itu tidak sekadar hadir dalam bentuk upacara ritual, melainkan internalisasi kebangsaan dalam ruang iman Kristen. Banyak orang Kristen membuat gereja hanya sebatas ruang suci, tempat di mana Allah berjumpa dengan umatNya dalam suasana yang sangat sakral. 
Gereja identik dengan sakral dan ritual semata, tanpa harus mencoba mengaktualisasi semua dimensi kehidupan di dalamnya. Gereja juga menjadi rumah pendidikan bagi umat dalam konteks warga negara. Bahkan sangat mungkin gereja menjadi rumah "politik".

Ada kecenderungan beberapa gereja mengalami alergi ketika dikaitkan dengan politik. Dalam konteks pendidikan politik bukan berarti gereja menjadi agen dari partai politik atau pergerakan politik tertentu. Konsep itu lebih kepada sebuah upaya untuk menyadarkan bahwa gereja ada dalam sebuah bangsa dan menjadi milik bangsa, sehingga rasa kebangsaan umat semakin tinggi. Kekristenan tidak lagi melihat ke belakang, dari mana ia datang, melainkan melihat sebuah tempat atau wilayah di mana ia lahir saat ini dan dibesarkan hingga akhir menutup mata. Sekali waktu nyanyian yang terdengar tidak lagi semata-mata lagu-lagu rohani dengan label Kristen, melainkan epik nasionalisme tentang kebesaran Tuhan di dalamnya.

Rekonstruksi iman dalam sebuah peristiwa Alkitab tidak menghilangkan fakta historis peristiwa itu. Paskah yang awal merupakan sebuah napak tilas kebangsaan tetap menjadi sebuah refleksi kebangsaan dalam kerangka beriman kepada Allah yang memberikan pembebasan. Peristiwa salib dijelaskan oleh
Yohanes sebagai sebuah ekspresi besarnya kasih Allah kepada dunia. Kata kuncinya adalah kasih, sehingga tanpa kasih tidak mungkin ada tindakan yang berujung pada peristiwa salib. Peristiwa Paskah merupakan peristiwa kasih, bukan hanya dalam suasana teologis namun juga dalam suasana yang lebih luas termasuk suasana kebangsaan atau nasionalisme.

Sikap nasionalisme dimulai dari kasih terhadap bangsa; itulah yang dilakukan Musa kala membela Israel di hadapan Allah, rela kehilangan hak surgawi demi bangsanya. Pembelaan terhadap bangsa ini juga harus seperti itu, rela kehilangan sesuatu yang berharga demi bangsa ini mendapatkan keselamatannya. Inilah nilai nasionalisme yang harus tertanam dalam kekristenan, bahwa gereja memiliki dan dimiliki oleh bangsa Indonesia, menjadi bagian yang inklusif bukan eksklusif. Ibadah gerejawi dalam perayaan Paskah tidak lagi diselenggarakan untuk sekadar membangun relasi iman melainkan juga relasi sosial dalam konteks nasionalisme.

Dalam lingkungan pendidikan, pada proses belajar di sekolah dengan mata pelajaran Pendidikan Agama Kristen, materi ajar tentang perayaan Paskah dapat menjadi cara untuk melakukan refleksi dan internalisasi sikap nasionalisme siswa. ${ }^{16}$ 
Internalisasi nasionalisme melihat peristiwa Paskah sebagai peristiwa kasih dalam rangka menebus bangsa Indonesia. Siswa diajarkan tentang salib yang menjadi sentral iman Kristen, titik balik untuk memanusiakan manusia agar memiliki nilai-nilai manusia yang manusiawi. Secara simultan penebusan itu menggapai skala nasional, di mana siswa diajarkan untuk memiliki dan mengasihi bangsa ini. Dengan mengasihi bangsa maka setiap orang terdorong untuk melakukan segala upaya untuk dapat menyelamatkan bangsanya.

Perayaan Paskah di Mesir telah memberikan rasa nasionalisme yang kuat kepada Israel, bahwa Allah membebaskan mereka dari penjajahan dan perbudakan oleh karena kasih. Perayaan yang mengambil setting peristiwa nasionalisme itu pun seharusnya menghasilkan implikasi reflektif tentang nasionalisme, termasuk dalam konteks nasionalisme Indonesia.

\section{KESIMPULAN}

Peristiwa Paskah di dalam Keluaran 12:1-51 tidak hanya berimplikasi teologis, yakni pada peristiwa salib tentang penebusan dosa. Peristiwa Paskah Israel di tanah Mesir merupakan momentum

\footnotetext{
${ }^{16}$ A.M. Wibowo, "Penanaman Nilai-nilai Nasionalisme Melalui Pendidikan Agama pada Sekolah Menengah Atas di Perbatasan Negara: Implementasi di SMAN 1 Jagoibabang, Kabupaten Bengkayang, Provinsi Kalimantan Barat", Jurnal Penamas, Vol. 28, No. 3, Oktober-Desember 2015: 404
}

pembebasan ilahi terhadap sebuah bangsa dari penjajahan, sehingga perayaan yang mengambil setting peristiwa tersebut patut mempertimbangkan momentum peristiwa nasionalisme. Gereja dan sekolah sebagai lembaga yang mengajarkan tentang peristiwa Paskah sudah saatnya melakukan proses pendidikan yang menyentuh nilai nasionalisme umat dan siswa, sehingga orang Kristen dapat menempatkan dirinya lebih nyata lagi sebagai bagian dari bangsa Indonesia.

\section{REFERENSI}

Achtemeier, Paul J. (gen. ed.), The HarperCollins Bible Dictionary, New York: HarperCollins, 1996

Alfaqi, Midran Zusron. "Melihat Sejarah Nasionalisme Indonesia Untuk Memupuk Sikap Kebangsaan Generasi Muda", Jurnal Civics, Vol. 13, No. 2 (Desember 2016)

Amrah. "Mengulik Pengembangan Nasionalisme Generasi Muda." Jurnal Publikasi Pendidikan, Vol. 6, No. 2, Juni 2016: 94.

Dyrness, William. Tema-tema dalam Teologi Perjanjian Lama, Malang: Gandum Mas, 2004

Fee, Gordon D. and Stuart, Douglas. How to Read The Bible for All its Worth, Michigan: Grand Rapids, 1982

Hendropriyono. "Ide dan Praksis NeoNasionalisme dalam Menghadapi Tantangan Globalisasi", Jurnal Filsafat UGM, Vol. 18, No. 1 (April 2008) Hillton, Andrew E. dan Walton, John H. Survei Perjanjian Lama, Malang: Gandum Mas, 1996.

Kaiser, Walter C. Teologi Perjanjian Lama, Malang: Gandum Mas, 2013 
Knight, George W. Adat Istiadat Alkitab dan Keunikannya dalam Gambar, Jakarta: BPK Gunung Mulia, 2015.

Ruslan, Idrus. "Membangun Nasionalisme Sebagai Solusi Untuk Mengatasi Konflik Sara di Indonesia”, Jurnal TAPIS, Vol. 10, No. 1, Januari-Juni 2010

Samarena, Desti. "Berteologi dalam

Konteks Indonesia Modern",

Evangelikal: Jurnal Teologi Injili dan

Pembinaan Warga Jemaat, Vol. 1, No.

1, Januari 2017

Schnittjer, Gary Edward. The Torah Story, Malang: Gandum Mas, 2015.

Simanjuntak, Junihot M. "Kristologi

Sebagai Pusat dalam Pembinaan Warga

Gereja”, Jurnal Teologi Stulos, Vol.

13, No. 1 (April 2014)

Wibowo, A.M. "Penanaman Nilai-nilai

Nasionalisme Melalui Pendidikan

Agama pada Sekolah Menengah Atas di

Perbatasan Negara: Implementasi di

SMAN 1 Jagoibabang, Kabupaten

Bengkayang, Provinsi Kalimantan

Barat", Jurnal Penamas, Vol. 28, No.

3, Oktober-Desember 2015

Ware, Steven L. "Cracking The Code of

Easter or, Understanding hy The Date of Easter 'Hops' All Over The

Calendars of March and April" Jurnal

Jaffray, Vol. 13, No. 2, Oktober 2015 